\title{
Internment in the United Kingdom During the Twentieth Century and Its Links to the Evolution of Immigration Detention
}

\author{
Stephanie J. Silverman*
}

Nathanson Centre on Human Rights, Crime and Security, Ignat Kaneff Building, 3067, Osgoode Hall Law School, York University, 4700 Keele Street, Toronto, Ontario M3J 1P3, Canada

\begin{abstract}
Immigration detention is cementing into a permanent aspect of border and immigration control in the United Kingdom. This article uses a historical examination of internment to contribute to a larger literature that unsettles the official record of detention policy as a natural development in an otherwise functioning immigration and border control bureaucracy. In so doing, I present an original overview of the First World War, Second World War, and Gulf War internments. My research findings demonstrate that wartime powers legislated in times of national distress have been repackaged as seemingly quotidian tools of immigration and asylum control. The results of this normalisation have included the reinforcement of a false logic of differentiation between citizens and threats, and between "good" and "bad" migrants; and an instrumentalisation of national insecurity to curtail the movements and basic rights of all individuals.
\end{abstract}

Keywords: Detention, internment, immigration, United Kingdom, public policy, history.

\section{INTRODUCTION: FROM WARTIME TO ROUTINE}

The laws and polices that were historically passed to legitimise internments in the United Kingdom (UK) during the World Wars and the Gulf War are the same ones that undergird many of that country's contemporary detention practices. This revelation is disturbing. Internment arose in the milieu of a general panic concerning fifth columns, saboteurs, and espionage during wartime. It was meant to last only so long as the foreign threat persisted. It is thus disconcerting that the laws and policies governing the expanding UK detention estate are the same ones that historically shepherded so-called "enemy aliens" to remote camps. Grappling with this revelation also opens up room for a more general discussion of the place and propriety of immigration detention in the UK today.

Through a critical analysis of historical policy development, this article engages internment with immigration detention in order to introduce the latter practice as well as to challenge some understandings central to its proliferation as a routine instrument of immigration control. Specifically, this article identifies and explores two significant, interrelated insights that emerge when detention is put into conversation with internment. First, UK governments may have been relying on a false logic distinguishing "good" from "bad" migrants when designing detention and internment policies. This logic is predicated on a static notion of

*Address correspondence to this author at the Nathanson Centre on Human Rights, Crime and Security, Ignat Kaneff Building, 3067, Osgoode Hall Law School, York University, 4700 Keele Street, Toronto, Ontario M3J 1P3, Canada; Tel: 1416736 5030; E-mail: sj.silverman@gmail.com categorical identities that essentialises and stigmatises thousands, if not millions, of people based on race, ethnicity, and nationality. Second, UK governments have repeatedly capitalised on periods of national insecurity to gain increased control over the liberty, autonomy and other core individual rights of individuals.

\section{A NOTE ON METHODS, TERMINOLOGY, AND CURRENT STATISTICS}

The three interments under discussion remain relatively under-explored in the migration studies and public policy literatures. This article is meant as a contribution to our understanding of the significance of the intersections amongst executive control over noncitizens, sovereign power, and security measures, particularly in relation to confinement. ${ }^{1}$ Building on research that connects different sites of detention throughout time and space within a national history, ${ }^{2}$ । attempt to situate the UK internments in their political contexts, and I use theoretical analysis to unpack their implications. Although focused on World War internments, this article indicates interesting parallels in justifications and political tactics related to the contemporary detention estate.

A few explanatory notes on terminology are in order. Alien as a legal, historical term refers to noncitizens subject to immigration control. Illegal alien remains a common term of American law, and illegal immigrant has become a term of art for pundits,

\footnotetext{
'See, e.g., Cornelisse, 2010; Hall, 2012; Mountz, Coddington, et al., 2012 ${ }^{2}$ Nethery, 2012; Welch, 2012; Welch \& Schuster, 2005. 
politicians, and the public. Enemy alien refers to aliens from particular states considered to be hostile towards the host state, usually during wartime.

Internment is the legal practice of detaining enemy aliens. The process of internment involves taking someone into official custody who is not formally charged with an offence. If held on security grounds, the internee does not enjoy the right to know the legal basis that warrants the internment. Some UK citizens were swept up in the internment programs due to their political beliefs, revocation of their naturalised citizenship statuses, or mistaken identities. The UK internments were also accompanied by deportations of refugees, resident foreign nationals, and enemy British subjects (subjects of the British Empire whose beliefs real or fabricated by others - caused them to become security concerns for the state).

Immigration detention refers to the holding of aliens in specific facilities for the purposes of realising an immigration-related goal (Flynn, 2011; Kalhan, 2010; Silverman and Massa, 2012). For the purposes of this article, the meaning of "immigration-related goal" encompasses larger concerns related to the migrationsecurity nexus, ${ }^{3}$ including an expansive understanding of security as impacting migrants' larger social circles. ${ }^{4}$

The UK immigration detention estate is amongst the largest in Europe, with the legal authority and operational capacity to detain some 3,500 people in conditions similar to prisons. From 2009 until the end of 2011, the UK Government detained between 2,000 and 3,000 people at any given time, with the most common category of detainees being people seeking asylum (Silverman \& Hajela, 2012). As of the end of March 2013, 2,853 people were in immigration detention, $6 \%$ fewer than the number recorded at the end of March 2012. Of those leaving immigration detention, $60 \%$ were removed from the country (HM Inspectorate of Prisons, 2014). It costs UK taxpayers between $£ 120$ and $£ 130$ per detainee per day (Silverman \& Massa, 2012: 670).

\section{THE ALIENS ACT 1905: THE LEGISLATIVE} FOUNDATIONS OF INTERNMENT AND DETENTION

The Aliens Act 1905 marks the start of the modern period of migration control in the UK. It presents a

\footnotetext{
${ }^{3}$ See, e.g., Bosworth \& Guild, 2008; de Londras, 2007; Huysmans \& Squire 2010; and Tirman, 2004.

${ }^{4}$ Harrison \&. Lloyd, 2012; Sørensen, 2012.
}

curious mix of anti-alienism and pro-asylum components. The Act also tends paradoxically towards both bureaucratic openness and firm executive control. For example, Section 1(3) of the Act is the first UK legal expression of the right of asylum for persons fleeing religious or political persecution. However, in calling for initial decisions on entry to be taken by immigration officers accompanied by medical officers, the Act also inscribes the administrative machinery for large-scale immigration control. ${ }^{5}$

Section 1(2) of the Act gives the Home Office unprecedented powers to "withhold leave" to "any immigrant who appears to [the immigration officer] to be an undesirable immigrant." Section $7(3)$ legalises the Home Secretary's powers to detain an alien indefinitely:

Any immigrant who is conditionally landed, and any alien in whose case an expulsion order is made ... and any alien in whose case a certificate has been given by a court, ... until the Secretary of State has decided upon his case, shall be liable to be kept in custody in such manner as the Secretary of State directs, and whilst in that custody shall be deemed to be in legal custody.

Section 1 (1) of the Directions of 4 December 1905 stipulates that aliens whose claims had been denied by the Home Office and who had been given deportation orders could be detained indefinitely.

\section{INTERNMENT DURING THE FIRST WORLD WAR}

The Aliens Restriction Act 1914 calls for the registration and monitoring of all resident aliens, regardless of immigration status. It also introduces a raft of new powers for the Home Secretary, and expands the Secretary's discretion to admit or refuse not only the "undesirable" aliens but also all aliens. The 1914 Act authorises the UK Government to designate some areas as off-limits to aliens. It also eliminates the 1905 Act's unconditional exception to immigration controls for aliens fleeing religious or political persecution. The Home Secretary's wide discretion was justified by the Government's contention that its officers were capable of distinguishing friendly from enemy aliens.

\footnotetext{
${ }^{5}$ See Wray, 2006.
} 
The 7 May 1914 sinking of the passenger liner Lusitania, and the rioting that followed, inflamed xenophobia in the UK and precipitated the subsequent internments (Gullace, 2005: 361). In August and September of that year, the Home Office published three circulars that prohibited an increasing number of aliens from travelling without permits and from relocating more than five miles from their places of residence (Sykes and Dane, 1916: 7). Then, on 15 May 1915, Prime Minister Herbert Asquith made public the Home Office's intention to intern 24,000 adult males of foreign nationality "for their own safety and that of the country" (Simpson, 1994: 13).

On the heels of the Home Office circulars, the first Defence of the Realm Act (DORA) was introduced to the House of Commons on 7 August 1914 - three days after war was declared - and written into legislation on 8 August 1914. DORA grants the Home Office a sweeping legislative competence and isolates the executive from the usual checks and balances on government in the UK. It passed all the required stages of the House of Commons virtually without debate and in a matter of minutes.

DORA Regulation 14B provides the Home Secretary with "competent naval or military authority" to intern anyone of "hostile origin or associations" (McDermott, 2005: 339 - 340). It authorises the trial by court-martial of persons contravening specified regulations "as if such persons were subject to military law and had on active service committed an offence" (Vorspan, 2005: 6). At any given time during the First World War, approximately 20 British enemy subjects were interned under DORA Regulation 14B powers (Simpson, 1988 - 1989: 231). DORA regulations persisted in spite of the protestations of Members of Parliament in 1916 and 1917 that they were inappropriate to the situation (Simpson, 1994: 5) and in the face of a court challenge brought in $R v$. Halliday ex parte Zadig. $^{6}$

The majority of internees were sent to wind-swept towns on the semi-autonomous Isle of Man. The Home Department decided who would be interned and the

\footnotetext{
${ }^{6} R$ v. Halliday ex parte Zadig challenged Regulation $14 \mathrm{~B}$ as ultra vires the Defense of the Realm Act. The point of contention revolved around the legitimacy of inferring from silence that Parliament approved a scheme of preventive detention, i.e. interment. However, the entire King's Bench contended that internment was a necessary device for winning the war, and both the Court of Appeal and the House of Lords rendered equally cursory judgments. Lord Atkinson, for example, articulated the rationale for his decision as follows: however 'precious' the personal liberty of the subject might be, it must be 'sacrificed to achieve national success in the war.' (Vorspan 2005: 22 $-23)$
}

War Office was responsible for guarding the sites (Winterbottom, 2000: 237). From August 1914 to May 1915, Germans and Austrians of military age were selectively arrested and interned. The number of internees reached 10,000 by late 1914 , and rose to 32,000 over the next two years. Wartime documentation recorded 24,450 internees at Knockaloe Moar and an additional 2,744 internees in the nearby town of Douglas (Cesarani, 1993: 35; Winterbottom 2000: 237). In total, of the $70-75,000$ people classified as enemy aliens in the UK, roughly 32,000 men of mostly German and Austrian nationalities were interned, and a further 10,000 were deported or repatriated (Kushner and Knox, 1999: 45; Shah 2000: 43). During this time, ships were also hired to function as internment sites (Panayi, 1993: 64).

By February 1919 the number of internees held in the Isle of Man camps and elsewhere dropped to about 19,831, of whom 16,442 were Germans; by May 1919, the figure totalled about 5,000 , consisting mainly of individuals unwilling to leave the UK (Ibid 62). For a five-year period following the end of the war, former enemy aliens were banned from entering the country, acquiring land, changing names, or gaining employment in the civil service (Cesarani, 1993: 39).

\section{INTERNMENT DURING THE SECOND WORLD WAR}

Initially granted as wartime contingencies, the Home Secretary's powers of incarceration of foreigners included, but also transcended, the enforcement of a court's recommendation for detention and/or deportation. The Secretary was empowered to detain or deport anyone not "conducive to the public good." Then-Home Secretary Edward Shortt described these powers as "administrative action[s] ... [taken] on behalf of the public" (Cohen, 1994: 46).

Tandem powers evolved for the police in order to enact and reinforce the Secretary's powers. Starting in 1919, the UK police force has theoretically known the whereabouts of all asylum seekers in the UK through its requirement of presentation within three months of arrival and report to the police any changes of address.

The Joint Imperial Committee began interning Jews and political adversaries in May 1938 (Seyfert, 1984). In January 1939, the Home Office published a White Paper describing its proposal to intern aliens "for ensuring safe custody and maintaining order and good behaviour." (Simpson, 1994: 80) The resultant Regulation 18B of the Defence (General) Regulations of 1939 was passed on 1 September 1939, two days 
before the declaration of war. As one of the Defence Regulations made by Order in Council under the Emergency Powers (Defence) Act 1939, the relevant regulations state:

If the Secretary of State has reasonable cause to believe any person to be of hostile origin or associations or to have been recently concerned in acts prejudicial to the public safety or the defence of the realm or in the preparation or instigation of such acts and by that reason thereof it is necessary to exercise control over him, he may make an order against that person directing that he be detained.

Some 70,000 Germans and Austrians then living in the country were immediately reclassified as enemy aliens, including approximately 55,000 asylum seekers fleeing from Nazi Germany and German-dominated Austria. In the first half of 1940, the Home Office began interning male enemy aliens residing in the coastal areas and, by May 1940, some 3,500 female enemy aliens were also ordered interned (Kochan, 1983: 1 2 ). The majority of internment orders were made in 1940 .

The Isle of Man once again served as the primary location for internment. On 25 June 1940, under Regulation 18B, Home Secretary Sir John Anderson issued internment orders for about 27,000 German, Austrian, and Italian enemy aliens (of a total population of about 93,000) (Rostow, 1944 - 1945: 495). Once again, most internees were not informed of the legal reasons warranting their internment, and their solicitors' visits were supervised (Simpson 1988 - 1989: 234). The largest internment camp was an unfinished housing estate at Huyton near Liverpool: at its maximum capacity, it hosted between 3,000 and 5,000 internees living mostly in tents, with Nazis, pro-Nazi sympathisers, and Jewish refugees residing side by side (Chappell 2005: 36; Kochan 1983: 68). Presaging a practice increasingly used in immigration detention, the authorities shuttled troublesome internees between the camps and the prisons (Simpson, 1994: 255).

By September 1941, as the internee population was dropping to about 8,500, the UK Government employed Regulation 18B to arrest approximately 1,847 British subjects (Rostow, 1944 - 1945: 495). The largest group was the core leaders of the British Union of Fascists, including Sir Oswald Mosley and his wife (Simpson, 1996: Footnote 7). An uncertain number of
British subjects were constrained by restrictions on residence, requirements to report changes of address, and curfews throughout the war. While the majority were held in camps, a small number of prominent internees were housed in prisons, notably Brixton Prison in London (Simpson, 1988 - 1989: 242). The UK Government also carried out at least 7,000 deportations to its former colonies (Seyfert, 1984: 171 $-176)$.

\section{THE IMMIGRATION ACT 1971}

After the war, immigration control policy developed in fits and starts. By the late-1960s, Parliament was growing increasingly dissatisfied with this piecemeal approach. A discussion of how to reform the process led to the Immigration Act 1971 and, with it, a formal, statutory basis for immigration detention (Squire, 2005: 54). The marked increase in arrivals of asylum seekers in the 1980s led to the Asylum and Immigration Appeals Act 1993, which authorises categorisation of migrants into risk-based groups who are then placed on an accelerated appeals process (Banks, 2008: 44 45; Harvey, 1997: 64). The subsequent Asylum and Immigration Act 1996 supplements and tightens this process.

\section{GULF WAR INTERNMENT AND THE CASE OF ABBAS SHIBLAK}

One month after the Iraqi invasion of Kuwait in August 1990, the Conservative government moved to prevent Iraqi nationals from entering the UK to study. By January 1991, all Iraqi nationals with leave to enter or remain in the UK were required to register with the police, and were prohibited from extending their stays.

After joining the American coalition and committing to war, Secretary of State Kenneth Baker formally issued orders to take into custody 110 Iraqi and Palestinian nationals who were legally resident in the UK. It has been reported that many of these internees had British spouses and children. The majority of the internees were students with study grants from the Iraqi government. Although most were interned under Immigration Act 1971 powers, 35 were subsequently reclassified as prisoners of war. Initially, the detainees were held in Pentonville Prison in London; most were subsequently transferred to Full Sutton in Yorkshire, and some remained in London in Wormwood Scrubs prison (Walsh, 1993: 306 - 308).

The UK has the dubious distinction of being the only Western member of the anti-Iraqi coalition to intern 
Iraqi nationals during the conflict. In a written statement to the House of Commons from 20 March 2003, thenHome Secretary David Blunkett remarked that: 'Many people will be aware that action taken in 1991 to detain large numbers of Iraqi citizens proved to be ineffective. I do not consider the action taken in 1991 to have been the most appropriate means to deal with the situation then.' (Hansard HC Deb 20 March 2003 vol 401 cc513WS). Apart from sporadic statements in Parliament and some memorial efforts, discussion of the Gulf War internment remains muted in the UK.

The Palestinian intellectual Abbas Shiblak was swept up in the internment. A progressive critic of Saddam Hussein, Shiblak had been granted indefinite leave to remain in the UK in 1987. His application to become a naturalised British citizen was under review when the Gulf War began. After a campaign organised by individuals and advocacy networks, Shiblak was released on 6 February 1991 after almost eleven months of internment/detention in Pentonville Prison under a deportation order. Shiblak (1993: 244) describes the experience thusly: 'we are in a democratic and free society, yet suddenly I found myself completely helpless and defenceless, held in prison and threatened with the destruction of my future without any reason being given, without any legal defence. It is a terror I do not wish on anyone.'

\section{DISCUSSION: IDENTIFICATION AND ISOLATION, THEN AND NOW}

As noted by Kushner and Cesarani (1993) and Gullace (2005), wartime exigencies, a Home Secretary's suspicions, or an inflamed media are not sufficient justifications for implementing internment without judicial review. In light of scale and population composition, dismissals of internment and detention as wartime collateral damage are also unconvincing. Moreover, a public appeal to trust the motives of the executive branch of government cannot justify the continuous renewal without public discussion of the powerful but supposedly exceptional DORA or Regulation 18B measures.

This article's examination of internment and detention in the UK yields at least two insights. Firstly, an easy distinction between enemy aliens and legitimate migrants is not possible. In the lead-up to the World Wars and the Gulf War, the UK Government tried to neutralise perceived threats emanating from within its territory. In so doing, it made sweeping assumptions about danger that incorporated nationality, gender, political beliefs, and foreignness into one caricature of alien. The wrong headedness of this position was manifest when, for instance, internees' British-born families and other commitments to sustaining a British life were ignored as irrelevant; Jews and Nazi sympathisers were interned together; and the progressive intellectual Abbas Shiblak was interned as an enemy because of his Iraqi nationality.

The experience of making false assumptions about core loyalties and truth-telling based on countries of origin is being repeated in the UK detention estate. Indeed, an analogous assumption animates the Government's contemporary practices of categorizing migrants into risk-based groups as well as its accelerated appeals process. The lesson learned from failed attempts to differentiate enemy from friendly aliens has not been brought to bear on the development of UK detention policy.

Secondly, this examination of internment and detention in the UK demonstrates how times of conflict open up space for the executive branch of government to gain more control over people's movements. DORA and Regulation 18B expanded the Home Secretary's discretionary power to detain from enemy aliens in wartime to all aliens at all times. Likewise, the Aliens Act 1905 and then the Immigration Act 1971 cemented the Home Secretary's monopoly of power over detention decisions. The UK Government's justifying its superseding of individual rights with a bugaboo of national security has normalised this centralisation of power.

The research in this article demonstrates how atmospheres of fear, distrust, and xenophobia combined with an official appeal to national security to lead to practices that override individuals' enjoyments of core rights to liberty, autonomy, and equality. The UK Government's repeated turns to large-scale internment and detention implicitly and explicitly promoted the view that such extreme actions constitute acceptable responses to the presence of aliens. Emergency powers of internment that were implemented in times of national distress were eventually consolidated and repackaged as instruments of detention in times of peace. As detention continues to calcify into a permanent aspect of border and immigration control in the UK, this article uses a historical examination of internment to contribute to a larger effort aimed at challenging the official presentation of detention policy as a natural development in an otherwise functioning immigration and border control bureaucracy. 


\section{REFERENCES}

Banks, J. (2008). 'The Criminalisation of Asylum Seekers and Asylum Policy.' Prison Service Journal 175: 43-49.

Bashford, A. and C. Strange (2002). 'Asylum-Seekers and National Histories of Detention.' Australian Journal of Politics and History 48(4): 19. http://dx.doi.org/10.1111/1467-8497.00273

Bosworth, M. (2012). 'Subjectivity and identity in detention: Punishment and society in a global age.' Theoretical Criminology 16(2): 123-140.

http://dx.doi.org/10.1177/1362480612441116

Bosworth, M. and M. Guild (2008). 'Governing Through Migration Control.' British Journal of Criminology 48(6): 703-719. http://dx.doi.org/10.1093/bjc/azn059

Cesarani, D. (1993). 'An Alien Concept? The Continuity of AntiAlienism in British Society before 1940.' The Internment of Aliens in Twentieth Century Britain. D. Cesarani and T. Kushner. London, Frank Cass and Company Limited: 25-52.

Chappell, C. (2005). Island of Barbed Wire: Internment on the Isle of Man in World War Two. London, Robert Hale.

Cohen, R. (1994). Frontiers of Identity: The British and the Others. London, Longman.

Cornelisse, G. (2010). Immigration Detention and Human Rights: Rethinking Territorial Sovereignty. The Netherlands, Martinus Nijhoff Publishers. http://dx.doi.org/10.1163/ej.9789004173705.i-384

Flynn, M. (2011). Immigration Detention and Proportionality. Global Detention Project Working Paper No. 4. Geneva, The Graduate Institute.

Gullace, N. (2005). 'Friends, Aliens, and Enemies: Fictive Communities and the Lusitania Riots of 1915.' Journal of Social History 39(2): 345-367. http://dx.doi.org/10.1353/jsh.2005.0137

HM Inspectorate of Prisons (2014). Monitoring places of detention: Fourth Annual Report of the United Kingdom's National Preventive Mechanism, 1 April 2012 - 31 March 2013. London, HM Inspectorate of Prisons. 2014: 48.

Hall, A. (2012). Border Watch: Cultures of Immigration, Detention, and Control. London, Pluto Press.

Hansard HC Deb 20 March 2003 vol 401 cc51-3WS.

Harrison, J. L. and S. E. Lloyd (2012). "Illegality at Work: Deportability and the Productive New Era of Immigration Enforcement." Antipode 44(2): 365-385. http://dx.doi.org/10.1111/j.1467-8330.2010.00841.x

Harvey, C. (1997). 'Restructuring Asylum: Recent Trends in United Kingdom Asylum Law and Policy.' International Journal of Refugee Law 9(1): 60-74. http://dx.doi.org/10.1093/ijr//9.1.60

Huysmans, J. and V. Squire (2010). 'Migration and security.' The Routledge Handbook of Security Studies. M. Dunn Cavelty and V. Mauer. Abingdon, Routledge: 169-179.

Kalhan, A. (2010). 'Rethinking Immigration Detention.' Columbia Law Review 110: 42-58.

Kochan, M. (1983). Britain's Internees in the Second World War. London, Macmillan Press Ltd.

Kushner, T. and D. Cesarani (1993). 'Alien Internment in Britain During the Twentieth Century: An Introduction.' The Internment of Aliens in Twentieth Century Britain. D. Cesarani and T. Kushner. London, Frank Cass and Company Limited: 1-24.

Kushner, T. and K. Knox (1999). Refugees in an Age of Genocide: Global, National and Local Perspectives during the Twentieth Century. London, Frank Cass.

McDermott, P.M. (2005). 'Internment during the Great War-A Challenge to the Rule of Law'. The University of New South Wales Law Journal 2(34): 330.
Mountz, A., K. Coddington, et al. (2013). "Conceptualizing detention: Mobility, containment, bordering, and exclusion." Progress in Human Geography 37(4). http://dx.doi.org/10.1177/0309132512460903

Nethery, A. (2012). 'Separate and Invisible: A Carceral History of Australian Islands.' Shima: The International Journal of Research into Island Cultures 6(01): 85-96.

Panayi, P. (1993). 'An Intolerant Act by an Intolerant Society: The Internment of Germans in Britain During the First World War.' The Internment of Aliens in Twentieth Century Britain. D. Cesarani and T. Kushner. London, Frank Cass and Company Limited: 53-75.

Rostow, E. V. (1944-1945). 'The Japanese American Cases-A Disaster.' Yale Law Journal 54: 489-533. http://dx.doi.org/10.2307/792783

Seyfert, M. (1984). 'His Majesty's Most Loyal Internees'. Exile in Great Britain: Refugees from Hitler's Germany. G. Hirschfeld. London, Berg Publishers: 163-194.

Shah, P. (2000). Refugees, Race, and the Legal Concept of Asylum in Britain. London, Cavendish Publishing, Ltd.

Shiblak, A. (1993). 'Internment Testimony.' The Internment of Aliens in Twentieth Century Britain. D. Cesarani and T. Kushner. London, Frank Cass and Company Limited: 241-244.

Silverman, S. J. and E. Massa (2012). 'Why Immigration Detention is Unique.' Population, Space and Place 18(06): 677-686. http://dx.doi.org/10.1002/psp.1720

Silverman, S. J. and R. Hajela (2012). Immigration Detention in the UK-Updated. Migration Observatory Briefings. Oxford, The Migration Observatory: 7.

Simpson, A. W. B. (1988-1989). 'Detention without Trial in the Second World War: Comparing the British and American Experiences.' Florida State University Law Review 16: 225268.

Simpson, A. W. B. (1994). In the Highest Degree Odious: Detention without Trial in Wartime Britain. Oxford, Clarendon Press. http://dx.doi.org/10.1093/acprof:oso/9780198259497.001.000 1

Simpson, A. W. B. (1996). 'Round Up the Usual Suspects: The Legacy of British Colonialism and the European Convention on Human Rights.' Loyola Law Review 41(4): 629-712.

Sørensen, N. N. (2012). 'Revisiting the Migration-Development Nexus: From Social Networks and Remittances to Markets for Migration Control.' International Migration 5(03): 61-76. http://dx.doi.org/10.1111/j.1468-2435.2012.00753.x

Squire, V. (2005). "Integration with diversity in modern Britain": New Labour on nationality, immigration and asylum.' Journal of Political Ideologies 10(1): 51-74. http://dx.doi.org/10.1080/1356931052000310245

Sykes, A. J. and L. Dane (1916). 'Report of the Commissioners appointed to review the Permits under which Alien Enemies are allowed to reside in Prohibited Areas.' Home Office Reports. T. Home Office. London, The Home Office 6.

Tirman, J., Ed. (2004). Maze of Fear: Migration and Security after 9/11. New York, New Press.

Vine, J. (2011). A Thematic Inspection of How the UK Border Agency Manages Foreign National Prisoners. London, UK Border Agency: 19.

Vorspan, R. (2005). 'Law and War: Individual Rights, Executive Authority, and Judicial Power in England During World War I.' Vanderbilt Journal of Transactional Law: 107.

Walsh, B. (1993). 'Detention and deportation of foreign nationals in the United Kingdom during the Gulf conflict.' The Gulf War 1990-91 In International and English Law. P. Rowe. London, Routledge: 304-332.

Welch, M. (2012). 'The Sonics Of Crimmigration In Australia: Wall of Noise and Quiet Manoeuvring.' British Journal of Criminology, 52(02), 324-344. http://dx.doi.org/10.1093/bjc/azr068 
Welch, M. and L. Schuster (2005). 'Detention of asylum seekers in the UK and USA: Deciphering noisy and quiet constructions.' Punishment \& Society 7(4): 397-417. http://dx.doi.org/10.1177/1462474505057117

Winterbottom, D. (2000). Economic History, 1830-1996. A New History of the Isle of Man. R. Chiverrell and J. Belchem. Liverpool, Liverpool University Press: 207-278.
Wray, H. (2006). 'The Aliens Act 1905 and the Immigration Dilemma.' Journal of Law and Society 33(2): 22. http://dx.doi.org/10.1111/j.1467-6478.2006.00359.x

Received on 16-12-2013 Accepted on 23-04-2014 Published on 23-05-2014

DOI: http://dx.doi.org/10.6000/1929-4409.2014.03.15

(C) 2014 Stephanie J. Silverman; Licensee Lifescience Global.

This is an open access article licensed under the terms of the Creative Commons Attribution Non-Commercial License (http://creativecommons.org/licenses/by-nc/3.0/) which permits unrestricted, non-commercial use, distribution and reproduction in any medium, provided the work is properly cited. 